\title{
are children capable of collective intentionality?
}

\author{
laura wildemann kane ${ }^{1}$ \\ the graduate center, \\ city university of new york - united states of america
}

abstract

The family presents an interesting challenge to many conceptions of collective activity and the makeup of social groups. Social philosophers define social groups as being comprised of individuals who knowingly consent to their group membership or voluntarily act to continue their group membership. This notion of voluntarism that is built into the concept of a social group rests upon a narrow conception of agency that is difficult to extend beyond ableminded autonomous adults. Families, however, are often comprised of members who supposedly lack this developed sense of agency and are therefore considered incapable of consenting to join or remain in a group: infants and small children. So, the family seems to be an odd fit for the designation of social group, even though it is often heralded as a paradigm example of one. In this paper I argue that children and infants are in fact agents who are capable of collective intentionality, especially in the context of the family where they act cooperatively and reciprocally with their caretakers. In doing so, I present an understanding of the family as a social group that has degrees of voluntarism for all members in the forms of joint readiness and joint commitment. I argue for this in three steps. First, I employ Margaret Gilbert's concepts of joint commitment and joint readiness as a framework for collective intentionality. Second, echoing Carol Gould, I argue that we ought to expand our understanding of agency beyond the ideal case. Third, I draw upon recent research from Michael Tomasello that demonstrate a child's ability to act cooperatively and reciprocally. Together these steps provide a strong foundation for the claim that children and infants are agents capable of collective intentionality within families.

key words: collective intentionality; agency; cooperation; family.

\section{¿son los niños capaces de una intencionalidad colectiva?}

resumen

La familia presenta un desafío interesante a muchas concepciones sobre la actividad colectiva y el diseño de grupos sociales. Los filósofos sociales definen grupos sociales como compuestos por individuos que conscientemente consienten ser miembros del grupo o voluntariamente actúan para continuar siendo miembros del mismo. Esta noción de voluntarismo, construida en el concepto de un grupo social, reposa sobre una estrecha concepción de agencia que es difícil de extender más allá de los adultos capacitados y autónomos. Las familias, sin embargo, están usualmente compuestas por miembros que supuestamente carecen de este sentido desarrollado de agencia y que, por lo tanto, son considerados incapaces de consentir en ingresar o permanecer en un grupo: infantes y niños pequeños. Entonces, la familia parece ser una adecuación extraña para la designación del grupo social aun cuando es frecuentemente anunciada como un ejemplo paradigmático de

${ }^{1}$ E-mail: laura.w.kane@gmail.com 
éste. En este artículo sostengo que los niños e infantes son, de hecho, agentes capaces de intencionalidad colectiva, especialmente en el contexto de la familia donde actúan cooperativa y recíprocamente con aquellos que los cuidan. De este modo, presento una comprensión de la familia como un grupo social que tiene grados de voluntarismo para todos los miembros en las formas de aptitud y compromiso conjuntos. Sostengo esto en tres pasos. Primeramente, empleo los conceptos de Margaret Gilbert de compromiso y actitud conjuntos como un marco para la intencionalidad colectiva. En segundo lugar, haciéndonos eco de Carol Gould, sostengo que debemos expandir nuestra comprensión de agencia más allá del caso ideal. Finalmente, me baso en una investigación reciente de Michael Tomasello que demuestra la habilidad del niño para actuar cooperativa y recíprocamente. Juntos, estos pasos proveen un fuerte fundamento a la afirmación de que los niños e infantes son agentes capaces de intencionalidad colectiva dentro de las familias.

palabras clave: intencionalidad colectiva; agencia; cooperación; familia.

\section{as crianças são capazes de uma intencionalidade coletiva?}

resumo

A família apresenta um desafio interessante a muitas concepções sobre a atividade coletiva e a configuração de grupos sociais. Os filósofos sociais definem grupos sociais como compostos por indivíduos que conscientemente consentem em ser membros do grupo ou que atuam voluntariamente para continuar sendo membros deste. Essa noção de voluntarismo, construída no conceito de um grupo social, repousa sobre uma estreita concepção de agência que é difícil de estender além dos adultos capacitados e autônomos. As famílias, no entanto, comumente estão compostas por membros que supostamente carecem desse sentido desenvolvido de agência e que, portanto, são considerados incapazes de consentir em ingressar ou permanecer em um grupo: infantes e crianças pequenas. A família, então, parece ser uma adequação estranha para a designação de grupo social ainda que seja frequentemente anunciada como um exemplo paradigmático do mesmo. Neste artigo argumento que as crianças e infantes são, de fato, agentes capazes de intencionalidade coletiva, especialmente no contexto da família onde agem cooperativa e reciprocamente com aqueles que os cuidam. Deste modo, apresento uma compreensão de família como um grupo social que tem graus de voluntarismo para todos os membros nas formas de boa vontade e compromisso conjuntos. Argumento isso em três etapas. Primeiro, emprego os conceitos de Margaret Gilbert de compromisso e atitude conjuntos como uma estrutura para a intencionalidade coletiva. Em segundo lugar, ecoando a Carol Gould, sustento que devemos expandir nossa concepção de agência para além do caso ideal. Por último, me baseio em uma pesquisa recente de Michael Tomasello que demonstra a habilidade da criança em agir cooperativa e reciprocamente. Juntas, essas etapas provém um fundamento forte à afirmação de que crianças e infantes são agentes capazes de intencionalidade coletiva dentro das famílias.

palavras-chave: intencionalidade coletiva; agência; cooperação; família. 
are children capable of collective intentionality?

The paradigm examples that illustrate collective intentionality - painting a house, making a sauce - typically demonstrate cooperative activity between two ideal agents who form temporary ad hoc social groups (cf. BRATMAN, 2009; cf. SEARLE, 2010). Thus, they ignore perhaps the most important cooperative activity - familial care - and the more enduring kind of group relationship that exists between family members.

The family presents an interesting challenge to many conceptions of collective activity and the makeup of social groups. Social philosophers define social groups as being comprised of individuals who knowingly consent to their group membership or voluntarily act to continue their group membership (cf. BRATMAN, 1999; cf. GILBERT, 1989; 2006; cf. TUOMELA, 2007). This notion of voluntarism that is built into the concept of a social group rests upon a narrow conception of agency that is difficult to extend beyond able-minded autonomous adults. Families, however, are often comprised of members who supposedly lack this developed sense of agency and are therefore considered incapable of consenting to join or remain in a group: infants and small children. So, the family seems to be an odd fit for the designation of social group, even though it is often heralded as a paradigm example of one (cf. GILBERT, 2006, p. 94).

There are two ways to remedy this tension. The first way necessitates that we stop calling the family a social group in light of the fact that some group members lack the agency to become or remain group members. This approach seems unsatisfactory, for surely the family is some kind of social group. The second way involves reconceiving the notion of agency required for social group membership so that adults, young children, and infants may indeed count as group members. In this paper I argue that children and infants are in fact agents who are capable of collective intentionality, especially in the context of the family where they act cooperatively and 
reciprocally with their caretakers. In doing so, I present an understanding of the family as a social group that has degrees of voluntarism for all members in the forms of joint readiness and joint commitment. I argue for this conclusion in three steps. First, I employ Margaret Gilbert's concepts of joint commitment and joint readiness as a framework for collective intentionality. Second, echoing Carol Gould, I argue that we ought to expand our understanding of agency beyond the ideal case. Third, I draw upon recent research from Michael Tomasello that demonstrate a child's ability to act cooperatively and reciprocally. Together these steps provide a strong foundation for the claim that children and infants are agents capable of collective intentionality within families.

\section{joint commitments and joint readiness}

Margaret Gilbert's account of collectively intentionality holds that social groups are comprised of at least two members who are jointly committed to some particular goal, belief, attitude or action. The joint commitment need not arise through an explicit agreement; rather, Gilbert argues that a sufficient condition for the genesis of a joint commitment is for each party to the shared action to verbally or physically expresses their personal readiness to participate in that action with the other party (GILBERT, 2014, p. 29). A central element of Gilbert's view is that those who act together understand themselves to be parties to a commitment of this kind, which translates to a commitment of the whole (that is, a group commitment) rather than a conjunction of all of the personal (individual) commitments of the parties (GILBERT, 2000, p. 158). In this sense, individuals constitute a social group if and only if each of them thinks of themselves and the others as a 'we' who share in some action, belief, attitude, or some similar attribute (GILBERT, 1989, p. 204). ${ }^{2}$ So, a joint commitment delineates who the members of a social group are, but it is the feeling of having a shared commitment - the knowledge of a group commitment - that gives meaning to

${ }^{2}$ Gilbert terms this a plural subject (cf. GILBERT, 1989). 
the social group qua social group for each of its members. ${ }^{3}$ For the family, this would mean that all family members must be jointly committed to some shared goal, such as reciprocal familial care, in which they continually act collectively toward its completion.

A further condition of Gilbert's account is her argument that joint readiness for participation in a joint action is sufficient for the genesis of a joint commitment (GILBERT, 2014, p. 33). This joint readiness is not a prior agreement, nor should it be confused with another type of joint readiness that occurs within an already existing social group. This second kind of joint readiness stipulates that the members of a social group are all reliably willing and prepared for action whenever it should arise, whether the time for action is imminent or a mere possibility (GILBERT, 1989, p. 207). Those who are jointly ready in this sense are not yet committed, but recognize that their participation in a joint activity 1) would be beneficial to other potential group members as well as themselves, and 2) would advance the progress toward a shared goal. Taken together, these three elements - being committed to act together, being ready to act together when the time comes, and having the disposition to act together with others - can be used to provide a comprehensive picture of what is entailed for one to jointly commit oneself to form or join a social group. Still, this framework does not tell us who is capable of making joint commitments or, at the very least, who is capable of joint readiness. Before fully discussing the family within the framework of joint commitment and joint readiness, it is necessary to explore how we ought to understand agency, for the way we define agency will undoubtedly influence just who is capable of collective intentionality.

\footnotetext{
${ }^{3}$ Soran Reader makes a similar argument for what constitutes relationships, though she emphasizes that the relationship itself need not be valued (i.e. a relationship between a slave owner and a slave is not valued) (READER, 2007, p. 73). She argues that relationships are a particular kind of interaction based on the deliberate engagement of agents with one another. So, one might be a member of a group of "persons who have received heart transplants" but that status, condition, or substantive property does not become a relation until one heart transplant patient seeks out another, becomes engaged with that patient by sharing common experiences, and these initial engagements sustain in the long term through friendship and so on (READER, 2007, p. 73-77).
} 


\section{basic agency $\mathcal{E}$ developed agency}

In Interactive Democracy, Carol Gould argues that the application and scope of human rights should be extended to cover individuals who fall outside of the typically restrictive definition of agency. This restricted definition is couched in the belief that normative agency is taken to ground human rights norms with respect to the fact that agents must "have a conception of a worthwhile life" - that is, agents must be capable of the capacity to choose a pursue a worthwhile life (GOULD, 2014, p. 37). Gould rightly argues that any account of agency that builds a notion of "having a conception" into its basic idea is bound to exclude some humans - most notably, children and the disabled. Arguments that treat children as potential persons only ignores the fact that, as Gould argues, even small babies display a sort of agency. More importantly, though, is the claim that the formulation of having a conception of the good life seems distinctively liberal individualist, and may not extend crossculturally (GOULD, 2014, p. 38).

Gould suggests instead that agency be understood as a relational concept with two distinct senses: basic agency, which should be understood as open and inclusive, and developed agency, which should be understood as the development or flourishing of one's basic agency (GOULD, 2014, p. 39). The first, basic sense of agency consists in intentionality or choice as a feature of human action, and is evident in human life activity as a mode or way of being. The second, developed sense of agency is characterized by the exercise of this basic agency in the development of capacities or the realization of long-term projects or goals - this can take both individual and collective forms - that is a process over time. This second sense of agency presupposes the capacity for choosing that is part of the basic sense of agency (GOULD, 2014, p. 39). This enables Gould's notion of basic agency to remain open to infants and the disabled. ${ }^{4}$

\footnotetext{
4 This account of agency is based on a social ontology of "individuals-in-relations," a term appear in Gould's earlier work, and proposes that individuals are fundamentally interdependent. Her social ontology sees relations as constitutive of individuals, yet not wholly constitutive as a communitarian
} 
Can infants and the intellectually disabled form joint commitments? If we take Gould's notion of agency as authoritative, then it seems possible. But why should we think that, say, small children are capable of cooperation and reciprocity, and can therefore be jointly ready or make joint commitments?

Gould's assertion that children especially are agents, and display some form of agency, is not exclusive to her. Joan Tronto mentions that care receivers often try to reciprocate the care that they receive, arguing that even small infants try to return care to their care givers (TRONTO, 2013, p. 152). Friedrich Froebel and John Dewey both claim that children are capable of successfully directing their own learning endeavors, and David Kennedy argues that children are able to effectively communicate and demonstrate new fact to adults (cf. FROEBEL, 1887; cf. DEWEY, 1902; cf. KENNEDY, 2012). Likewise, Raimo Tuomela, drawing upon Michael Tomasello's research, claims that young children are capable of agency and, therefore, we-mode thinking (TUOMELA, 2007, p. 62). To give credence to these claims, it is worth exploring just how much young children display agency - especially with respect to cooperative endeavors - to see if they are in fact capable of forming joint commitments or, to a lesser degree, at least capable of being jointly ready.

\section{children as intentional agents}

Michael Tomasello argues that humans have ultra-cooperative tendencies, and these tendencies play a crucial role in the evolution of human culture. Human beings engage in two fundamentally cooperative processes toward this end: 1) we actively teach one another things, and these lessons are not only reserved for kin, and 2) we have a tendency to imitate others in the group simply with the motivation to be like them (TOMASELLO, 2009, p. XIV). Humans are altruistic in the sense that they donate information to others for their own use. Humans also cooperatively agree upon social 
norms of conformity that may be backed by various potential punishments or sanctions for those who resist conforming (TOMASELLO, 2009, p. XV). Because of these two tendencies, Tomasello argues that human cultures are based on fundamentally cooperative processes and, to an unprecedented degree, human beings are adapted for acting and thinking cooperatively in cultural groups. He argues further that children are equipped to participate in cooperative groupthink through a special kind of cultural intelligence that encourages shared intentionality (TOMASELLO, 2009, p. XVI).

Tomasello focuses on identifying children's naturally occurring cooperative tendencies by testing for altruism and collaboration; specifically, he presents evidence that children, from around the time of their first birthdays, are already helpful and cooperative in many, though not all, situations. Further, this disposition is not learned from adults; it comes naturally (TOMASELLO, 2009, p. 4). What happens later on in a child's life influences their development, often away from these naturally cooperative tendencies: cooperativeness becomes mediated by things that influence judgments of likely reciprocity and concern for how others in the group treat them or judge them. Children then begin to internalize many culturally specific social norms that aide in conformity (TOMASELLO, 2009, p. 4$).^{5}$

Further, Tomasello's experiments demonstrate that children's helping behavior is mediated by empathetic concern, suggesting that infants' naturally occurring empathetic or sympathetic responses to the plight of another affect their tendency to help that other person out (TOMASELLO, 2009, p. 13). Paul Bloom (2014, p. 48)

\footnotetext{
5 Tomasello defines the three main types of human altruism by the "commodity" involved: goods (being generous with sharing food), services (fetching an out of reach object), and information (sharing information and attitudes is to be informative) (TOMASELLO, 2009, p. 5).

With respect to a "helping" experiment, Tomasello and partners tested 14-18 month olds to see how much they helped out an adult in need. The parameters were identified that first, infants need to be able to perceive others' goals in a variety of situations, and second, they must have the altruistic motive to help the adults out (TOMASELLO, 2009, p. 7). There is evidence to suggest that human's helping behavior is not created by a human-like cultural environment, specifically because the same environments applied to primates do not yield the same results, suggesting that there is something hard-wired about our altruism as infants (TOMASELLO, 2009, p. 11).
} 
corroborates this finding with his own, claiming that infants attempt to soothe someone they perceive to be in pain. Infants also supply information altruistically; they inform others of things helpfully, accurately interpret intentions that are directed at them, and they understand imperatives in a cooperative fashion, meaning that they recognize that imperatives are typically communicated as desires (e.g. "I'd like some water") and automatically want to fulfill the desire in a cooperative way. This suggests that they understand the cooperative logic of helping (TOMASELLO, 2009, p. 19). ${ }^{6}$ With this is mind, Tomasello argues that we need to recognize that even young children already have some shared sense of intentionality - they take themselves to be part of some larger "we" intentionality. Without this dimension of "we" identity and rationality, it is impossible to explain why children take it upon themselves to actively enforce social norms on others from a third-party stance, especially the kinds of norms that are based on constitutive rules (and in a sense, arbitrary) and not only based upon cooperation (TOMASELLO, 2009, p. 40). ${ }^{7}$ They value conformity (both their own and the conformity of others) to the group - a value of "we-ness" that has its original basis on identification with significant-other individuals like parents and classmates (TOMASELLO, 2009, p. 41). Further, children seem to feel committed to joint goals, and prefer that all participants get the coveted reward instead of caring only about their own satisfaction (TOMASELLO, 2009, p. 66). So, it seems that children are indeed capable of displaying some form of agency,

\footnotetext{
${ }^{6}$ Young children also have an understanding of equitable distribution; 25-month olds and school-aged children typically select an equitable distribution over a selfish distribution, or, if challenged about an unfair distribution, they almost always square things up (TOMASELLO, 2009, p. 25).

7 Children respect conventional norms in which no harm is involved (TOMASELLO, 2009, p. 34). Children also actively seek out what they are supposed to do to follow certain norms so that they can behave accordingly (TOMASELLO, 2009, p. 35). When playing a known game with an unfamiliar (foreign) puppet, children will scold or stop the puppet when the puppet does not play the game the correct way. Children don't just disapprove of the way the puppet plays the game, but mention that the puppet is playing incorrectly because of the way that "we" play the game. The significance of this study concerns the fact that the norm enforced is not just regulative, but constitutive - this means that children do not just follow conventional norms because of how they are supposed to instrumentally guide action (to please adults or garner a reward), but because they view the conventional norms as supra-individual entities that carry social force independent of such instrumental considerations (TOMASELLO, 2009, p. 38).
} 
and this type of agency seems at least on par with Gould's account of how we should define basic agency.

\section{joint readiness in the family}

To return to Gilbert's theory of joint commitments, it should now be evident that at the very least, infants and small children are capable of joint readiness in both respects that Gilbert has in mind: children have a natural disposition toward cooperating with others, and children also do cooperate with others when given the opportunity, demonstrating that they possess a readiness to act collectively with others toward group goals. ${ }^{8}$ While it remains unchanged that infants require immense amounts of care and concern that they are unable to reciprocate, and it is indeed a stretch to claim that children are capable of forming joint commitments, it should at least be clear that children are more than capable of collective intentionality and, hence, collective action toward group goals because they recognize the significance that other group members place on shared goals. Although children may not be committed members of the group, their readiness to participate in group activity is sufficient for communicating approval of the group goals, as well as for laying the path to eventually become a group member when their basic sense of agency becomes developed. So, the notion of joint readiness, as a characteristic of joint commitments, enables young children to essentially act as though they are part of a social group with a shared goal. This is most clearly evident in the family where, as we have seen above, children - even infants - try to reciprocate care through small cooperative gestures.

Carol Gould mentions a specific type of reciprocity for the family, called cooperative reciprocity, which is meant to capture a relation among individuals who are

\footnotetext{
${ }^{8}$ In the case of the intellectually disabled, there remains, at least, agency in the basic sense. Hence, those who are unable to equally or substantially reciprocate because of an intellectual disability or injury are still able to cooperate in the sense that they respond to their caregivers and, in some cases, demonstrate appreciation for the care they are receiving.
} 
all engaged in activities towards common ends, in this case, the well-being of family members (GOULD, 2004, p. 44). She argues that caring about achieving this shared end is a compelling reason for family members to pay attention to their own responsibility for the joint undertaking in addition to the concern over the continued participation of other family members (GOULD, 2004, p. 45). An important aspect of familial care involves the development of agency, especially for the family's youngest members. By receiving care from other family members and participating in caring activities through joint readiness, children will arrive at a developed sense of agency that includes a conception of the good based upon their experiences with their family members. This developed sense of agency leads children who have grown into young adulthood to identify a conception of the good that they are willing to make their own. This conception of the good will most likely involve the maintenance of their family's group goal. Their developed sense of agency enables them to fully join the family as a committed member (meaning that they are now capable of being held accountable to other members), and to do so voluntarily. Thus, they willingly commit to remain members of the family that they were brought up into because they have identified this family, and the group goal of the family, as fitting within their conception of the good life. So, although children and infants may only initially possess a basic sense of agency, they are nevertheless agents capable of collective intentionality within families.

\section{references}

BRATMAN, Michael E. Faces Of Intention: Selected Essays On Intention And Agency. Cambridge, U.K: Cambridge University Press, 1999. Print.

BRATMAN, Michael E. Shared Agency. In: MANTZAVINOS, Chrysostomos (Ed). Philosophy of The Social Sciences: Philosophical Theory And Scientific Practice.. Cambridge, UK: Cambridge University Press, 2009.

DEWEY, John. The Child and the Curriculum. Chicago: University of Chicago Press, 1902.

FROEBEL, Friedrich; HAILMANN, Willian. The Education of Man. New York: D. Appleton and Co, 1887.

GILBERT, Margaret. On Social Facts. Routledge: Print, 1989.

GILBERT, Margaret. Sociality And Responsibility: New Essays In Plural Subject Theory. 
Lanham, Md: Rowman \& Littlefield Publishers, 2000.

GILBERT, Margaret. A Theory Of Political Obligation: Membership, Commitment, And The Bonds Of Society. Oxford: Clarendon Press [U.A.], 2006.

GILBERT, Margaret. Joint Commitment: How We Make The Social World. Oxford: Oxford University Press, 2014.

GOULD, Carol C. Rethinking Democracy: Freedom And Social Cooperation In Politics, Economy And Society. Cambridge University Press, 1988.

GILBERT, Margaret. Globalizing Democracy And Human Rights. Cambridge: Cambridge University Press, 2004. Print.

GILBERT, Margaret. Interactive Democracy: The Social Roots Of Global Justice. Cambridge: Cambridge University Press, 2014.

KENNEDY, D. Lipman, Dewey, And The Community Of Philosophical Inquiry. In: Education And Culture. 28: 36-53, 2012.

READER, Soran. Needs And Moral Necessity. London: Routledge, 2007.

SEARLE, John R. Making The Social World. Oxford University Press, 2010.

TOMASELLO, Michael. Why We Cooperate. Cambridge, Mass: MIT Press, 2009.

TRONTO, Joan. C. Caring Democracy: Markets, Equality, And Justice. New York: New York University Press, 2013.

TUOMELA, Raimo. The Philosophy Of Sociality: The Shared Point Of View. Oxford: Oxford University Press, 2007.

received in: 19.01.2017

accepted in: 21.02.2017 